\title{
LITERASI INFORMASI MASYARAKAT PESISIR DALAM PROGRAM PEMBERDAYAAN PEREMPUAN DI KECAMATAN CIPATUJAH TASIKMALAYA
}

\author{
Neneng Komariah ${ }^{1}$, Pawit M Yusup ${ }^{2}$,Saleha Rodiah ${ }^{3}$, Encang Saepudin ${ }^{4}$ \\ ${ }^{1,2,3,4}$ Program Studi Ilmu Informasi \& Perpustakaan \\ ${ }^{1}$ neneng.komariah@unpad.ac.id, ${ }^{2}$ pawit.m.yusup@unpad.ac.id, ${ }^{3}$ saleha.rodiah@unpad.ac.id, \\ ${ }^{4}$ encang.saepudin@unpad.ac.id
}

\begin{abstract}
This research examined information literacy in coastal community towards woman empowerment program in Cipatujah District Tasikmalaya Regency. It used mixed methods and technique of collecting data were questionnaire, interviews, focus group discussion, observation and literature study. The research aims to determine the level of information literacy in coastal community towards woman empowering program, started from planning, executing, benefit decision, and evaluation of woman empowerment program. The benefit of this research is a form of evaluation, especially against government policy implementation of Tasikmalaya Regency. The results showed levels of community literacy towards woman empowerment program started from planning, executing, benefit decision, and evaluation can be categorized as positive. It means the community have been already literate. It is based on a statistical calculation results illustrate that the median value is smaller than the value of the score and the value of score is less than the value of the third quartile. Based on the results of data processing, it can be concluded that the coastal community in the Cipatujah District - Tasikmalaya Regency already literate towards woman empowerment program.
\end{abstract}

Keywords: Literacy, Information, Woman Empowerment

ABSTRAK - Penelitian ini mengkaji mengenai Literasi Informasi Masyarakat Pesisir dalam Program Pemberdayaan Perempuan di Kecamatan Cipatujah Kabupaten Tasikmalaya. Dengan menggunakan mixed methods dan teknik pengumpulan data melalui penyebaran angket, wawancara, Focus Group Discussion, observasi, dan studi pustaka, penelitian ini bertujuan untuk mengetahui tingkat literasi Masyarakat Pesisir dalam Program Pemberdayaan Perempuan mulai tahap perencanaan, pelaksanaan, pengambilan manfaat, dan evaluasi program pemberdayaan masyarakat. Manfaat penelitian ini yakni sebagai bentuk evaluasi program terutama terhadap implementasi kebijakan pemerintah Kabupaten Tasikmalaya. Hasil penelitian menunjukkan tingkat literasi masyarakat Pesisir terhadap program pemberdayaan perempuan baik pada tahap pe-rencanaan, pelaksanaan, pengambilan manfaat, dan evaluasi program dapat dikategorikan positif artinya masyarakat sudah literat. Hal ini didasarkan pada hasil perhitungan statistic yang menggambarkan bahwa nilai median lebih kecil dari nilai skor dan nilai skor lebih kecil dari nilai kuartil III. Berdasarkan hasil pengolahan data, penelitian ini dapat disimpulkan bahwa Masyarakat Perisisir di Kecamatan Cipatujah Kabupaten Tasikmalaya sudah literat terhadap program pemberdayaan perempuan.

Kata kunci: Literasi, Informasi, Pemberdayaan, Masyarakat, Perempuan

\section{PENDAHULUAN}

Negara Indonesia merupakan negara dengan garis pantai tropis terpanjang atau terpanjang ke dua di dunia dengan panjang 81 ribu $\mathrm{km}$. Sekitar 5,8 juta $\mathrm{km}^{2}$ atau $3 / 4$ wilayahnya berupa lautan (Sukardi, 2012). Kondisi tersebut tentunya merupakan sumber daya alam yang sangat besar yang mampu menyokong perekonomian sebuah negara. Melimpahnya kekayaan alam Indonesia khusunya di bidang perikanan tidak sebanding dengan kondisi perekonomian rakyatnya. Sekitar 16,2 juta nelayan di Indonesia atau sekitar $44 \%$ dari jumlah nelayan yang mencapai 37 juta jiwa hidup di 
bawah ambang kemiskinan (Hakim, 2008). Besarnya angka kemiskinan dalam masyarakat nelayan di Indonesia tentunya tidak sebanding dengan ketersediaan sumber daya perikanan yang ada. Sumber daya perikanan merupakan yang terbesar di dunia, tetapi kemampuan produksi, pengolahan, peningkatan nilai tambah dan daya saing rendah (Kamiso, 2012).

Desa Sindang Kerta adalah salah satu Desa di Kecamatan Cipatujah yang mempunyai luas wilayah $1500 \mathrm{Ha}$ dengan jumlah penduduk sebanyak 5380 jiwa yang terdiri dari 2673 lakilaki dan 2707 perempuan dengan jumlah kepala keluarga 1702 KK. Jumlah keluarga miskin 370 KK dengan persentase $21 \%$ dari jumlah keluarga yang ada di Sindang Kerta.

Dilihat dari topografi dan kontur tanah, Sindang Kerta secara umum berupa dataran rendah dan dataran tinggi serta sebgaian merupakan daerah pesisir pantai dengan suhu berkisar antara 27 s/d 30 derajat celcius. Secara teoritis, masyarakat pesisir didefinisikan sebagai masyarakat yang tinggal dan melakukan aktifitas sosial ekonomi yang terkait dengan sumberdaya wilayah pesisir dan lautan. Dengan demikian, secara sempit masyarakat pesisir memiliki ketergantungan yang cukup tinggi dengan potensi dan kondisi sumberdaya pesisir dan lautan. Namun demikian, secara luas masyarakat pesisir dapat pula didefinisikan sebagai masyarakat yang tinggal secara spasial di wilayah pesisir tanpa mempertimbangkan apakah mereka memiliki aktifitas sosial ekonomi yang terkait dengan potensi dan kondisi sumberdaya pesisir dan lautan.
Dalam kerangka sosiologis, masyarakat pesisir, khususnya masyarakat nelayan, memiliki perilaku yang berbeda dengan katakanlah masyarakat petani/agraris. Perbedaan ini sebagian besar disebabkan karena karakteristik sumberdaya yang menjadi input utama bagi kehidupan sosial ekonomi mereka. Masyarakat nelayan akrab dengan ketidakpastian yang tinggi karena secara alamiah sumberdaya perikanan bersifat invisible sehingga sulit untuk diprediksi. Sementara masyarakat agraris misalnya memiliki ciri sumberdaya yang lebih pasti dan visible sehingga relatif lebih mudah untuk diprediksi terkait dengan ekspetasi sosial ekonomi masyarakat. Dalam kondisi seperti ini maka tidak jarang ditemui karakteristik masyarakat nelayan yang keras, sebagian temparemental dan tidak jarang yang boros karena ada persepsi bahwa sumberdaya perikanan "tinggal diambil" di laut (Satria, 2009).

Hal tersebut sedikit berbeda dengan pendapat Bahri (1995). Dia mengemukakan bahwa lingkungan fisik nelayan mempunyai karakteristik yang berbeda dengan petani. Sumberdaya perikanan mempunyai sifat sulit diramal serta sasaran target operasi penangkapannya hidup dan liar. Hal ini membuat usaha perikanan mempunyai resiko kerusakan dan kerugian yang tinggi serta pola pendapatan yang fluktuatif.

Kesulitan melepaskan diri dari belenggu kemiskinan karena mereka didera oleh beberapa keterbatasan di bidang kualitas sumberdaya manusia, akses dan penguasaan teknologi, pasar, dan modal. Kebijakan dan implementasi programprogram pembangunan untuk masyarakat 
di kawasan pesisir hingga saat ini masih belum optimal dalam memutus mata rantai belenggu kemiskinan dan meningkatkan kesejahteraan mereka (Kusnadi 2009).

Dalam keadaan ekonomi yang tidak menentu, membuat nelayan harus mampu untuk menyesuaikan diri dengan kondisi yang ada. Penyesuaian ini antara lain dengan memanfaatkan anggota rumah tangga untuk membantu meningkatkan pendapatan keluarga. Dalam hal ini, istri para nelayan merupakan anggota rumah tangga yang memiliki potensi dalam membantu meningkatkan pendapatan keluarga.

Tiga pendekatan kemiskinan yang bisa dijadikan dasar untuk pengentasan kemiskinan yaitu pendekatan kultural, struktural, dan alamiah. Pendekatan ini bisa dilakukan baik secara parsial maupun bersamaan dapat dipakai untuk menjelaskan penyebab kemiskinan di kalangan kaum perempuan, baik secara ekonomi, politik, sosial, dan budaya.

Pertama, pendekatan secara kultural sebagian masyakat kita masih dipengaruhi secara kuat oleh budaya tradisional yang berideologi patriarki. Yaitu fenomena ketimpangan struktural berupa keterbatasan kaum perempuan untuk memperoleh pendidikan, memperoleh akses ekonomi (misalnya bekerja untuk memperoleh penghasilan dan bukan sebatas menjalankan peran sebagai ibu rumah tangga), berorganisasi, dan lain sebagainya masih tetap berlaku. Kedua, kemiskinan struktural berekses pada timbulnya kemiskinan kultural dalam wujud rendahnya pendidikan dan keterampilan sebagian besar perempuan (terutama di perdesaan). Sementara itu, kemiskinan alamiah menjelaskan adanya sebagian kaum perempuan yang bersikap pasrah terhadap posisi dirinya dalam kehidupan rumah tangga dan masyarakat, karena secara sadar menyadari demikianlah kodratnya sebagai seorang perempuan.

Sedangkan Surjono dan Nugroho (2007) menyatakan terdapat tiga pendekatan dalam pemberdayaan masyarakat miskin, yakni (1) pendekatan yang terarah artinya pemberdayaan masyarakat harus terarah dan berpihak kepada orang miskin, (2) pendekatan kelompok, artinya secara bersama-sama untuk memudahkan pemecahan masalah yang dihadapi, dan (3) pendekatan pendampingan, artinya dilakukan selama proses pembentukan dan penyelenggaraan kelompok masyarakat miskin perlu didampingi oleh pendampingan yang profesional sebagai fasilitator, komunikator, dan dinaminisator terhadap kelompok untuk mempercepat tercapainya kemandirian.

Penduduk wanita yang jumlahnya lebih banyak dibandingkan dengan penduduk pria merupakan sumber daya pembangunan yang cukup besar. Literasi informasi aktif pria dan wanita dalam setiap proses pembangunan akan mempercepat tercapainya tujuan pembangunan. Wanita-wanita nelayan mempunyai potensi untuk meningkatkan pendapatan masyarakat nelayan, dimana posisi wanita yang selama ini hanya berfungsi sebagai ibu rumah tangga ditingkatkan sebagai pencari nafkah. Untuk itu, perlu diadakannya pemberdayaan bagi istri-istri nelayan. Optimalisasi peran wanita nelayan dalam pembangunan pesisir hanya dapat dilakukan melalui integrasi kebijakan pembangunan dan pemberdayaan perempuan ke dalam kebijakan 
nasional, propinsi atau kabupaten/kota baik pada ranah perencanaan, pelaksanaan, pemantauan maupun evaluasi pembangunan.

Pemberdayaan perempuan adalah upaya pemampuan perempuan untuk memperoleh akses dan kontrol terhadap sumberdaya ekonomi, politik, sosial, budaya agar perempuan dapat mengatur diri dan meningkatkan rasa percaya diri untuk mampu berpatisipasi aktif untuk menyelesaikan berbagai masalah yang timbul di lingkungan sekitarnya. Perempuan dengan jumlah yang sangat besar merupakan modal social yang potensial bagi kelangsungan pembangunan bangsa. Sejalan dengan pernyataan tersebut Mengenai konsep pemberdayaan perempuan Hikmat menyatakan sebagai berikut:

“...Konsep pemberdayaan dalam wacana pembangunan masyarakat selalu dihubungkan dengan konsep mandiri, partisipasi, jaringan kerja dan keadilan. Pada dasarnya, pemberdayaan diletakkan pada kekuatan tingkat individu dan sosial. Literasi informasi merupakan komponen penting dalam pembangkitan kemandirian dan proses pemberdayaan. Sebaiknya orang-orang harus terlibat dalam proses tersebut sehingga mereka dapat lebih memperhatikan hidupnya untuk memperoleh rasa percaya diri, memiliki harga diri dan pengetahuan untuk mengembangkan keahlian baru. Prosesnya dilakukan secara kumulatif sehingga semakin banyak keterampilan yang dimiliki seseorang semakin baik pula kemampuan partisipasinya.." (Hikmat, 2004).

Berdasarkan uraian diatas maka masalah yang diangkat akan dirumuskan dalam bentuk pertanyaan penelitian yaitu Bagaimana Literasi
Informasi Masyarakat Pesisir dalam Program Pemberdayaan Perempuan Di Kecamatan Cipatujah Kabupaten Tasikmalaya. Selanjutnya dari perumusan masalah tersebut, dapat diidentifikasi beberapa masalah sebagai berikut:

1. Mengetahui Literasi Informasi Masyarakat Pesisir dalam Program Pemberdayaan Perempuan pada tahap perencanaan?

2. Mengetahui Literasi Informasi Masyarakat Pesisir dalam Program Pemberdayaan Perempuan pada tahap pelaksanaan?

3. Mengetahui Literasi Informasi Masyarakat Pesisir dalam Program Pemberdayaan Perempuan pada tahap pengambilan manfaat?

4. Mengetahui Literasi Informasi Masyarakat Pesisir dalam Program Pemberdayaan Perempuan pada tahap Evaluasi?

Berdasarkan rumusan masalah penelitian yang diangkat yakni Bagaimana Literasi Informasi Masyarakat Pesisir dalam Program Pemberdayaan Perempuan Di Kecamatan Cipatujah Kabupaten Tasikmalaya. Selanjutnya penelitian ini bertujuan untuk;

1. Mengetahui tingkat Literasi Informasi Masyarakat Pesisir dalam Program Pemberdayaan Perempuan pada tahap perencanaan.

2. Mengetahui tingkat Literasi Informasi Masyarakat Pesisir dalam Program Pemberdayaan Perempuan pada tahap pelaksanaan.

3. Mengetahui tingkat Literasi Informasi Masyarakat Pesisir dalam Program Pemberdayaan Perempuan pada tahap pengambilan manfaat. 
4. Mengetahui tingkat Literasi Informasi Masyarakat Pesisir dalam Program Pemberdayaan Perempuan pada tahap Evaluasi.

\section{TINJAUAN PUSTAKA}

Teori yang digunakan sebagai acuan dalam penelitian ini adalah teori dari Charles O. Jones. Jones (1984:166) mengemukakan tiga aktivitas yang penting dalam implementasi kebijakan publik, yaitu organization, interpretation, and application.

1. Organization: the establishment or rearrangement of resources, unit and methods for putting a policy into effect;

2. Interpretation: the translation of program language (often contaned in a statute) into acceptable and feasible plans and directive;

3. Application: the routine provision of service, paymens, or other agree upon objectives of instrument.

Berdasar pada apa yang dikemukakan Jones tersebut, maka masalah pemberdayaan masyarakat sebagai implementasi kebijakan publik semakin lebih jelas dan luas, dimana implementasi itu merupakan proses yang memerlukan tindakantindakan sistematis dari organisasi, interpretasi, dan aplikasi.

Berdasarkan pada kerangka pemikiran yang telah diuraikan, maka yang dimaksud dengan implementasi kebijakan adalah serangkaian aktivitas untuk mencapai tujuan sebagaimana yang telah digariskan dalam kebijakan tersebut. Penelitian ini mengkaji tentang model pemberdayaan perempuan masyarakat pesisir sebagai upaya dari implementasi Program
Pemberdayaan Keluarga Fakir Miskin (P2KFM), dimana (P2KFM) adalah suatu program pemerintah dalam upaya pemberdayaan masyarakat fakir miskin (keluarga) yang terintegrasi untuk adanya Literasi informasi aktif masyarakat yang berbentuk pikiran, tenaga, keahlian dan materi untuk terwujudnya masyarakat mandiri dan meningkatkan kesejahteraannya. Menurut Jones, tiga aktivitas yang penting dalam implementasi kebijakan publik yaitu organization, interpretation, and application. Bila ketiga aktivitas tersebut dilaksanakan dengan baik, akan berpengaruh terhadap pencapaian tujuan kebijakan itu sendiri. Kerangka penelitian ini secara garis besar tergambar dalam bagan di bawah ini.

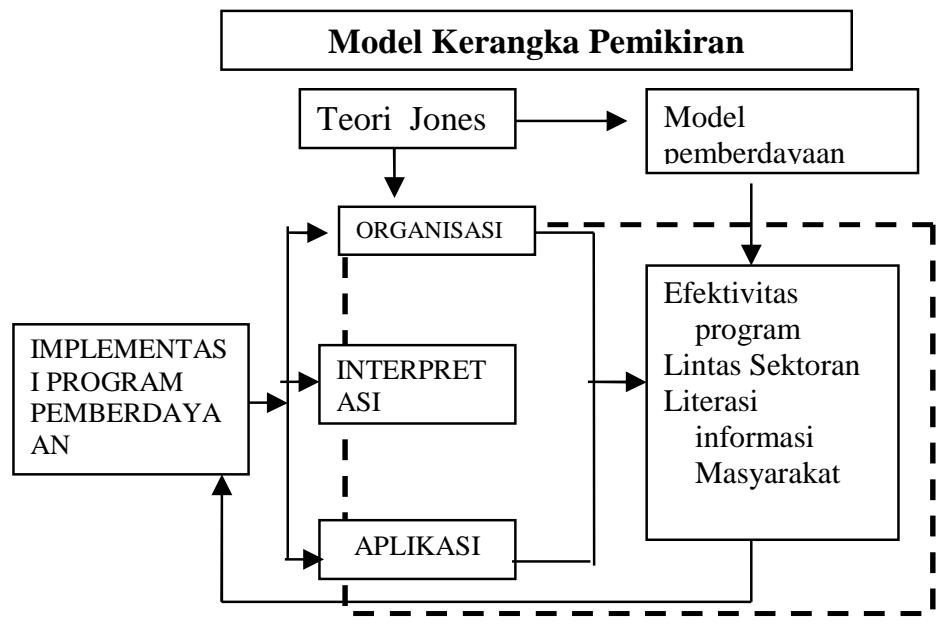

Gambar 1 Kerangka Penelitian

Rangkaian penelitian tentang Literasi Informasi Masyarakat Pesisir dalam Program Pemberdayaan Perempuan Di Kecamatan Cipatujah Kabupaten Tasikmalaya akan dilaksanakan sesuai dengan mekanisme penelitian. Secara singkat mekanisme penelitian dapat dilihat pada bagan di bawah ini: 




Gambar 2. Mekanisme Penelitian

\section{METODE PENELITIAN}

Metode yang digunakan dalam penelitian ini adalah metode mixed methods. Penelitian ini merupakan suatu langkah penelitian dengan menggabungkan dua bentuk penelitian yang telah ada sebelumnya yaitu penelitian kualitatif dan penelitian kuantitatif. Menurut Creswell (2010: 5), penelitian campuran merupakan pendekatan penelitian yang mengkombinasikan antara penelitian kualitatif dengan penelitian kuantitatif. Menurut pendapat Sugiyono (2011: 404) menyatakan bahwa metode penelitian kombinasi (mixed methods) adalah suatu metode penelitian yang mengkombinasikan atau menggabungkan antara metode kuantitatif dengan metode kualitatif untuk digunakan secara bersama-sama dalam suatu kegiatan penelitian, sehingga diperoleh data yang lebih komprehensif, valid, reliable dan obyektif.

Munculnya metode mixed methods ini mulanya hanya mencari usaha penggabungan antara data kualitatif dengan data kuantitaif (Creswell, 2010:22). Diperjelas lagi oleh Tashakkori dan Teddi dalam bukunya yang berjudul Mixed Methodology, bahwa mengombinasikan pendekatan kualitatif dan kuantitatif ini muncul setelah adanya debat yang berkepanjangan antara dua paradigma yang menjadi pedoman dari peneliti, kedua paradigma tersebut adalah positivis/empiris yang menjadi dasar konseptual dari metode kuantitatif dan paradigm konstruktivis/fenomenologi yang menjadi dasar dari metode kualitatif (2010: 3-4).

Disain penelitian yang digunakan dalam penelitian ini adalah sequential exploratory, yaitu mengumpulkan dan menganalisis data kualitatif kemudian mengumpulkan dan menganalisis data kuantitatif. Dalam penelitian ini lebih menekankan pada metode kualitatif (McMillan, 2010: 402). Sependapat dengan yang dikatakan oleh McMillan, Creswell (2010: 317-318) yaitu pada tahap pertama akan diisi dengan pengumpulan dan analisis data kualitatif, kemudian pengumpulan dan menganalisis data kuantitatif. Penggabungan data kuantitatif dengan data kualitatif ini biasanya didasarkan pada hasilhasil yang telah diperoleh sebelumnya dari tahap pertama. Prioritas utama pada tahap ini lebih ditekankan pada tahap pertama, dan proses penggabungan diantara keduanya terjadi ketika peneliti menghubungkan antara analisis data kualitatif dengan pengumpulan data kuantitatif. 
Pada penelitian ini, data kuantitatif digunakan untuk menjelaskan data kualitatif. Data kualitatif ini didapatkan melalui FGD dan wawancara dengan partisipan secara mendalam.

Metode kualitatif digunakan untuk memperoleh gambaran mengenai Membentuk model pemberdayaan perempuan masyarakat pesisir untuk penguatan ekonomi keluarga miskin Sedangkan untuk metode kuantitatif digunakan untuk Mengidentifikasi permasalahan tentang peran serta perempuan masyarakat pesisir dalam membantu perekonomian keluarga; Mengidentifikasi berbagai bentuk pemberdayaan perempuan masyarakat pesisir yang telah dilaksanakan. Mengidentifikasi dan menelaah berbagai kendala yang ada dalam upaya pemberdayaan perempuan masyarakat pesisir. Instrumen yang digunakan adalah angket.

\section{HASIL DAN PEMBAHASAN}

Pada bagian ini akan dibahas mengenai analisis data lapangan terkait dengan tujuan penelitian. Data lapangan berupa data kuantitatif mengenai literasi informasi masyarakat tentang pelaksanaan program pemberdayaan perempuan. Kuesioner yang diberikan kepada responden, berupa pernyataan tertutup mengenai Literasi informasi masyarakat dalam pelaksanaan program pemberdayaan perempuan di Kecamatan Ciapatujan Kabupaten Tasikmalaya. Setiap pernyataan yang diajukan, responden hanya perlu menjawab satu pilihan jawaban yang tersedia. Butir-butir pernyataan yang diajukan mengacu pada tolak ukur yang telah ditetapkan sebelumnya. Jawaban-jawabannyang tercantum dalam kuesioner mengacu pada skala likert. Pertanyaan yang ada dalam kuesioner masing-masing jawaban diberi skor sebagai berikut.

Tabel 1 Alternatif Jawaban Responden dan Skor Penilaian

\begin{tabular}{|l|c|c|}
\hline $\begin{array}{l}\text { Pilihan } \\
\text { jawaban }\end{array}$ & \multicolumn{2}{|c|}{$\begin{array}{c}\text { Skor masing-masing } \\
\text { pernyataan }\end{array}$} \\
\hline & $\begin{array}{l}\text { Pernyataan } \\
\text { positif }\end{array}$ & $\begin{array}{l}\text { Pernyataan } \\
\text { negatif }\end{array}$ \\
\hline $\begin{array}{l}\text { Sangat tidak } \\
\text { setuju }\end{array}$ & 1 & 5 \\
\hline Tidak setuju & 2 & 4 \\
\hline $\begin{array}{l}\text { Tidak ada } \\
\text { pendapat }\end{array}$ & 3 & 3 \\
\hline Setuju & 4 & 2 \\
\hline Sangat setuju & 5 & 1 \\
\hline
\end{tabular}

Setelah dilakukan uji validitas dan reliabilitas, selanjutnya adalah menganalisis data yang telah didapatkan dengan mengggunakan model analisis deskriptif. Model analisis ini menjelaskan pernyataan responden dengan mendeskripsikannya melalui penggunaan tabel dan pengukurannya menggunakan skala likert. Berdasarkan hal tersebut, maka jumlah skor dari seluruh responden adalah:

Tabel 2 Jumlah Skor Seluruh Responden

\begin{tabular}{|l|l|}
\hline Maksimal & 50 responden $\times 5=250$ \\
\hline Minimal & 50 responden $\times 1=50$ \\
\hline Median & 50 responden $\times 3=150$ \\
\hline Kuartil I & 50 responden $\times 2=100$ \\
\hline Kuartil III & 50 responden $\times 4=200$ \\
\hline
\end{tabular}

Jumlah skor tersebut kemudian dianalisis dengan menggunakan beberapa pendekatan (Sugiyono, 2008), untuk menentukan seberapa besar tingkat Literasi informasi masyarakat, sebagai berikut: 
a. Jika Kuartil III < Skor < Maksimal; artinya sangat positif (Literasi informasi masyarakat dinilai aktif).

b. Jika Median < Skor < Kuartil III; artinya positif (Literasi informasi masyarakat dinilai cukup aktif).

c. Jika Kuartil I < Skor < Median; artinya negatif (Literasi informasi masyarakat dinilai kurang aktif).

d. Jika Minimal < Skor < Kuartil I; artinya sangat negatif (Literasi informasi masyarakat dinilai tidak aktif).

Apabila dipersentasekan, maka besar tingkat Literasi informasi masyarakat dapat dihitung berdasarkan rumusan sebagai berikut:

Skor maksimal

Pada bagian ini akan diukur mengenai tingkat Literasi informasi masyarakat berdasarkan tolak ukur yang ada pada masing-masing variabel. Untuk mempermudah pengolahan data, data yang diperoleh kemudian diolah dengan menggunakan Microsoft Excel. Berikut adalah penjelasannya berdasarka kepada hasil nasilis terhadap masingmasing indicator dari setiap variabel penelitian

\section{Literasi informasi dalam Pengambilan Keputusan/ Perencanaan}

Variabel ini memiliki empat indikator yaitu a) Informasi mengenai program pemberdayaan perempuan didapatkan melalui kelurahan atau RT/RW setempat, Pemberitahuan mengenai adanya program pemberdayaan perempuan bagi masyarakat dilakukan secara jelas, c) Masyarakat mencari tahu lebih jauh mengenai program pemberdayaan perempuan, d) Pernah memberikan masukan gagasan/ ide dalam program pemberdayaan perempuan. Berikut adalah perhitungan dari tiap indicator/ tolak ukur tersebut.

Tabel 3 Literasi informasi dalam Pengambilan Keputusan/ Perencanaan

\begin{tabular}{|c|c|c|c|}
\hline No & Tolak ukur & Skor & Median \\
\hline 1 & $\begin{array}{l}\text { Informasi mengenai } \\
\text { program } \\
\text { pemberdayaan } \\
\text { perempuan } \\
\text { didapatkan melalui } \\
\text { kelurahan atau } \\
\text { RT/RW setempat }\end{array}$ & 194 & 150 \\
\hline 2 & $\begin{array}{l}\text { Pemberitahuan } \\
\text { mengenai adanya } \\
\text { program } \\
\text { pemberdayaan } \\
\text { perempuan bagi } \\
\text { masyarakat dilakukan } \\
\text { secara jelas }\end{array}$ & 211 & 150 \\
\hline 3 & $\begin{array}{l}\text { Masyarakat mencari } \\
\text { tahu lebih jauh } \\
\text { mengenai program } \\
\text { pemberdayaan } \\
\text { perempuan }\end{array}$ & 167 & 150 \\
\hline 4 & $\begin{array}{l}\text { Pernah memberikan } \\
\text { masukan gagasan/ ide } \\
\text { dalam program } \\
\text { pemberdayaan } \\
\text { perempuan Pernah } \\
\text { memberikan masukan } \\
\text { gagasan/ ide dalam } \\
\text { program } \\
\text { pemberdayaan } \\
\text { perempuan }\end{array}$ & 129 & 150 \\
\hline \multicolumn{2}{|r|}{ Total } & 701 & 150 \\
\hline \multicolumn{2}{|r|}{ Rata-rata } & 175.25 & 150 \\
\hline
\end{tabular}

Data di atas menggambarkan bahwa Literasi informasi masyarakat dalam pengambilan keputusan/ Perencanaan program pemberdayaan perempuan cukup tinggi. Hal ini terlihat dari ratarata skor yang diperoleh adalah 175.25. Skor tersebut jauh lebih tinggi dari skor median yakni 
150. Data tersebut menunjukkan bahwa nilai Median < nilai Skor < nilai Kuartil III. Hal ini artinya positif (Literasi informasi masyarakat dinilai cukup aktif). Tingkat Literasi informasi ini terjadi disebabkan oleh keterbukaan para pengelola program pemberdayaan perempuan yang dimonitoring oleh pihak pemerintahan.

Apabila skor komulatif dari sub variabel ini dipresentasekan maka dapat dihitung sebagai berikut:

Tingkat Literasi informasi V1= ---------x 100
$=70.1 \%$

\section{Literasi informasi Masyarakat}

\section{Pelaksanaan Program}

dalam

Variabel ini memiliki dua indikator yaitu a) Setiap kegiatan dalam program pemberdayaan perempuan selalu didokumentasikan b) Selalu ikut serta dalam pengadministrasian kegiatan. Berikut adalah perhitungan dari tiap indicator/ tolak ukur tersebut:

Tabel 4 Literasi informasi Masyarakat dalam Pelaksanaan Program

\begin{tabular}{|l|l|l|l|}
\hline No & Tolak ukur & Skor & Median \\
\hline 1 & $\begin{array}{l}\text { Setiap kegiatan } \\
\text { dalam program } \\
\text { pemberdayaan } \\
\text { perempuan selalu } \\
\text { didokumentasikan }\end{array}$ & 163 & 150 \\
\hline 2 & $\begin{array}{l}\text { Selalu ikut serta } \\
\text { dalam } \\
\text { pengadministrasian } \\
\text { kegiatan }\end{array}$ & 147 & 150 \\
\hline Total & 310 & 150 \\
\hline & Rata-rata & 155 & 150 \\
\hline
\end{tabular}

Data di atas menggambarkan bahwa Literasi informasi masyarakat dalam pelaksanaan program desa mandiri pangan cukup tinggi. Hal ini terlihat dari rata-rata skor yang diperoleh adalah 155 Walaupun Skor tersebut tidak terlalu jauh dari skor median yakni 150 namun sudah berada di atas skor median. Data tersebut menunjukkan bahwa nilai Median < nilai Skor < nilai Kuartil III. Hal ini artinya positif (Literasi informasi masyarakat dinilai cukup aktif). Tingkat Literasi informasi ini terjadi disebabkan oleh kegiatan pendokumentasian kegiatan.

Apabila skor komulatif dari sub variabel ini dipresentasekan maka dapat dihitung sebagai berikut:

$$
\begin{gathered}
\text { Tingkat Literasi informasi V2 }=\frac{155}{250}=0 \\
=62 \%
\end{gathered}
$$

\section{Literasi informasi Masyarakat dalam}

\section{Pengambilan Manfaat}

Variabel Literasi informasi masyarakat dalam pengambilan manfaat memiliki 2 indikator. Kedua indikator tersebut adalah a) Adanya program pemberdayaan perempuan membantu pemecahan masalah usaha yang dihadapi anggota, dan b) Keterampilan anggota kelompok menjadi meningkat dengan pendampingan yang diberikan. Berikut adalah perhitungan dari tiap indicator/ tolak ukur tersebut: 
Tabel 5 Literasi informasi Masyarakat dalam Pengambilan Manfaat

\begin{tabular}{|l|l|l|l|}
\hline No & Tolak ukur & Skor & Median \\
\hline 1 & $\begin{array}{l}\text { Adanya program } \\
\text { pemberdayaan } \\
\text { perempuan } \\
\text { membantu } \\
\text { pemecahan masalah } \\
\text { usaha yang dihadapi } \\
\text { anggota }\end{array}$ & 145 & 150 \\
\hline 2 & $\begin{array}{l}\text { Keterampilan } \\
\text { anggota kelompok } \\
\text { menjadi meningkat } \\
\text { dengan } \\
\text { pendampingan yang } \\
\text { diberikan }\end{array}$ & 165 & 150 \\
\hline & Total & 310 & 150 \\
\hline \multicolumn{2}{|c|}{ Rata-rata } & 155 & 150 \\
\hline
\end{tabular}

Data di atas menggambarkan bahwa Literasi informasi masyarakat dalam pengambilan manfaat program desa mandiri pangan cukup tinggi. Hal ini terlihat dari rata-rata skor yang diperoleh adalah 155. Walaupun Skor tersebut tidak terlalu jauh dari skor median yakni 150 namun masih berada di bawah skor median. Walaupun Skor tersebut tidak terlalu jauh dari skor median yakni 150 namun sudah berada di atas skor median. Data tersebut menunjukkan bahwa nilai Median < niali Skor < nilai Kuartil III. Hal ini artinya positif (Literasi informasi masyarakat dinilai cukup aktif). Tingkat Literasi informasi ini terjadi disebabkan oleh kegiatan pendokumentasian kegiatan. Apabila skor komulatif dari sub variabel ini dipresentasekan maka dapat dihitung sebagai berikut;

Tingkat Literasi informasi V3 $=\frac{155}{-------x ~} 100$
$=62 \%$

\section{Literasi informasi masyarakat dalam tahap evaluasi}

Variabel Literasi informasi masyarakat dalam kegiatan evaluasi memiliki empat indikator. Keempat indikator tersebut adalah a) Selalu memberi masukan kepada pengelola program pada akhir pelaksanaan kegiatan. b) Sering mengadu pada pengelola progran mengenai pelaksaan kegiata. c) Suka membantu pengelola program dalam menyusun pelaporan kegiatan, dan d) Membantu pengumpulan data/ bahan pelapran kegiatan. Nilai sekor dari masing-masing indicator dapat dilihat pada tabel di bawah ini.

Tabel 6 Literasi informasi Masyarakat dalam Evaluasi

\begin{tabular}{|l|l|l|l|}
\hline No & Tolak ukur & Skor & Median \\
\hline 1 & $\begin{array}{l}\text { Selalu memberi masukan } \\
\text { kepada pengelola } \\
\text { program pada akhir } \\
\text { pelaksanaan kegiatan }\end{array}$ & 107 & 150 \\
\hline 2 & $\begin{array}{l}\text { Sering mengadu pada } \\
\text { pengelola progran } \\
\text { mengenai pelaksaan } \\
\text { kegiata }\end{array}$ & 150 & 150 \\
\hline 3 & $\begin{array}{l}\text { Suka membantu } \\
\text { pengelola program dalam } \\
\text { menyusun pelaporan } \\
\text { kegiatan }\end{array}$ & 138 & 150 \\
\hline 4 & $\begin{array}{l}\text { Membantu pengumpulan } \\
\text { data/ bahan pelapran } \\
\text { kegiatan }\end{array}$ & 131 & 150 \\
\hline \multicolumn{2}{|c|}{ Total } & 526 & 150 \\
\hline \multicolumn{2}{|c|}{ Rata-rata } & 131.5 & 150 \\
\hline
\end{tabular}

Data di atas menggambarkan bahwa Literasi informasi masyarakat pada tahap evaluasi program desa mandiri pangan cukup tinggi. Hal ini terlihat dari rata-rata skor yang diperoleh adalah 131.5. Skor tersebut berada di bawah skor median yakni 150, dan berada di atas kwartil I. Berdasarkan pada data yang tergambarkan bahwa 
nilai Kuartil I < nilai Skor < nilai Median. Hal ini artinya negatif (Literasi informasi masyarakat dinilai kurang aktif).

Apabila skor komulatif dari sub variabel ini dipresentasekan maka dapat dihitung sebagai berikut;

Tingkat Literasi informasi V4= ---------x 100
$=52.6 \%$

Berdasarkan skor komulatif dari masingmansing sub variabel maka tingkat literasi masyarakat dalam program pemberdayaan perempuan dapat dikelompokkan menjadi dua bagian. Bagian pertama yakni literasi masyarakat dalam pengambilan keputusan/ perencanaan program, perlaksanaan program, dan pengambilan manfaat adalah positif. Hal ini karena skor sub variabel ini menunjukkan bahwa nilai Median < niali Skor < nilai Kuartil III. Hal ini artinya positif (Literasi informasi masyarakat dinilai cukup aktif). Hal ini dapat dilihat pada tabel di bawah ini.

Tabel 7 Perhitungan Skor Komulatif Setiap Sub Variabel

\begin{tabular}{|c|c|c|c|c|c|}
\hline SubVariabel & $\begin{array}{c}\text { Nilai } \\
\text { Median }\end{array}$ & & Skor & & $\begin{array}{c}\text { Kuartil } \\
\text { III }\end{array}$ \\
\hline $\begin{array}{c}\text { Pengmbilan } \\
\text { keputusan }\end{array}$ & 150 & $<$ & 175.25 & $<$ & 200 \\
\hline $\begin{array}{c}\text { Pelaksanaan } \\
\text { program }\end{array}$ & 150 & & 155 & $<$ & 150 \\
\hline $\begin{array}{c}\text { Pengambilan } \\
\text { manfaat }\end{array}$ & 150 & & 155 & $<$ & 150 \\
\hline
\end{tabular}

Bagian kedua yakni Literasi informasi masyarakat dalam tahap evaluasi kurang positif. Hal ini karena nilai Kuartil I < nilai Skor < nilai Median. Hal ini artinya negatif (Literasi informasi masyarakat dinilai kurang aktif). Hal ini dapat dilihat pada tabel berikut ini:

Tabel 8 Perhitungan Skor Komulatif Setiap Sub Variabel

\begin{tabular}{|c|c|c|c|c|c|}
\hline $\begin{array}{c}\text { Sub } \\
\text { Variabel }\end{array}$ & $\begin{array}{c}\text { Kuartil } \\
\text { I }\end{array}$ & & Skor & & $\begin{array}{c}\text { Nilai } \\
\text { Median }\end{array}$ \\
\hline $\begin{array}{c}\text { Evaluasi } \\
\text { program }\end{array}$ & 100 & $<$ & 131.5 & $<$ & 150 \\
\hline
\end{tabular}

Apabila skor komulatif dari variabel ini dihitung maka Literasi informasi masyarakat pada program pemberdayaan perempuan adalah positif. Hal ini terlihat dari Data menunjukkan bahwa nilai Median < niali Skor < nilai Kuartil III. Hal ini artinya positif (Literasi informasi masyarakat dinilai cukup aktif).Hal ini dapat dilihat pada tabel berikut ini:

Tabel 9 Perhitungan Skor Komulatif Variabel

\begin{tabular}{|c|c|c|c|c|c|}
\hline SubVariabel & $\begin{array}{c}\text { Nilai } \\
\text { Median }\end{array}$ & & Skor & & $\begin{array}{c}\text { Kuartil } \\
\text { III }\end{array}$ \\
\hline $\begin{array}{c}\text { Literasi } \\
\text { informasi } \\
\text { masyarakat }\end{array}$ & 150 & $<$ & 154.18 & $<$ & 200 \\
\hline
\end{tabular}

Apabila skor komulatif ini dipresentasekan maka dapat dihitung sebagai berikut:

Tingkat Literasi informasi $V=\frac{154.18}{}$
$=61.67 \%$

\section{SIMPULAN}

Berdasarkan kepada hasil pengolahan data sementara penelitian ini dapat disimpulkan bahwa Literasi Informasi Masyarakat Pesisir dalam Program Pemberdayaan Perempuan Di Kecamatan Cipatujah Kabupaten Tasikmalaya 
adalah positif. Hal ini terlihat dari Data menunjukkan bahwa nilai Median $(150)<$ niali Skor $(154.18)<$ nilai Kuartil III (200). Hal ini artinya positif (Literasi informasi masyarakat dinilai cukup)

\section{DAFTAR PUSTAKA}

Dwidjowijoto, Rian Nugroho, (2007). Manajemen Pemberdayaan, Sebuah Pengantar dan Panduan Untuk Pemberdayaan Masyarakat. Jakarta, Gramedia

Hikmah, Istiana. (2007). Gender dalam Rumah Tangga Masyarakat Nelayan. Jakarta: Badan Riset Kelautan dan Perikanan.

Hikmat, Marry. (2001). Strategy Pemberdayaan Masyarakat. Bandung: Humaniora Ulama Press.

Kamiso, H. N., (2012). Pengantar Ilmu Perikanan 3. Bahan Ajar Pengantar Ilmu Perikanan. Universitas Gadjah Mada. Yogyakarta.

Kusnadi. (2003). Akar Kemiskinan Nelayan. Yogyakarta: LkiS.

Kusnadi. (2007). Jaminan Sosial Nelayan. Yogyakarta: LKiS Pelangi Aksara.

Nurfaizah, Eva. (2013). Implementasi Pemberdayaan Masyarakat Sebagai Upaya Pengentasan Kemiskinan Melalui Program Aksi Desa Mandiri Pangan Di Desa Karangkepoh, Kecamatan Karanggede, Kabupaten Boyolali. Semarang; Ikip PGRI.

Pranarka, A.M.W \& Onny S. Prijono. (1996). Pemberdayaan Konsep, Kebijakan dan Implementasi. Jakarta: CSIS

Roesmidi dan Riza Risyanty. (2006). Pemberdayaan masyarakat. Sumedang: Alqaprint

Satria, A. (2009). Ekologi Masyarakat Nelayan. Yogyakarta: LKiS.

Sumodiningrat, Gunawan. (1999). Pemberdayaan Masyarakat dan Jaring Pengaman Sosial. Jakarta: PT. Graincdia Pustaka Utama.

Suharto, Edi. (2006). Membangun Masyarakat Memberdayakan Rakyat. Bandung: PT. Rcfika Aditama.

Soetomo. (2012). Pemberdayaan Masyarakat Mungkinkah Muncul Antitesisnya. Yogyakarta: Puataka Pelajar.
Sugiyono. (1999). Statistika Untuk Penelitian. Bandung: Alfabeta

Sugiyono. (2006). Metode Penelitian Bisnis. Bandung: Alfabeta.

Sugiyono. (2011). Metode Penelitian Kuantitatif kualitatif dan $R \& D$. Bandung: Alfabeta

Suharto, Edi. (2006). Membangun Masyarakat Memberdayakan Rakyat. Bandung: Refika Aditama

Sukardi, (2012). Peran Perikanan dan Kelautan dalam Kehidupan Manusia. Bahan Ajar Pengantar Ilmu Perikanan. Universitas Gadjah Mada. Yogyakarta. 